\title{
Rivalidades históricas: la imagen de Brasil en la prensa ilustrada porteña a finales del siglo XIX
}

\author{
María Silvina Sosa Vota ${ }^{1}$
}

\begin{abstract}
Resumen: El último cuarto del siglo XIX fue un espacio de tiempo en el cual los Estados nacionales en América Latina hicieron un gran esfuerzo de consolidación, momento que coincidió con una fuerte disputa simbólica en torno a las identidades nacionales. El escenario internacional será de fundamental importancia a la hora de consolidar esas identidades y será objetivo de este trabajo pensar esta cuestión a partir de los imaginarios sobre Brasil en Argentina, partiendo de la idea de que Brasil se presentaba una alteridad que, en contraste, permitiría afirmar una idea de lo propio. La prensa ilustrada será un espacio en el que se plasmarán las ideas e imaginarios que circulaban. El Mosquito de Buenos Aires, uno de los periódicos de crítica y sátira política en el cual la imagen ocupaba un espacio central, será la fuente principal del trabajo que pretende analizar las formas de representación de Brasil en las caricaturas, focalizando en las connotaciones culturales de esas representaciones y los movimientos políticos que alentaron al caricaturista a interpretar la realidad y plasmarla de esa manera en particular.
\end{abstract}

Palabras clave: caricaturas, Buenos Aires, alteridad, conflicto.

\section{Rivalidades históricas: a imagem do Brasil na imprensa ilustrada portenha no final do século XIX}

Resumo: As últimas décadas do século XIX foram uma época na qual os Estados nacionais na América Latina fizeram um grande esforço para se consolidar. Esse momento coincidiu com uma forte disputa simbólica ao redor das identidades nacionais. O cenário internacional será de fundamental importância no momento de consolidar essas identidades e será objetivo deste trabalho pensar essa questão a partir dos imaginários sobre o Brasil na Argentina, partindo da ideia de que o Brasil se presentava como uma alteridade que, no contraste, permitiria formar uma noção sobre o próprio. A imprensa ilustrada será um espaço no qual serão refletidas as ideias e imaginários que circulavam. El Mosquito de Buenos Aires, um dos jornais de crítica e sátira política onde a imagem ocupava um lugar central, será a fonte principal do trabalho que pretende fazer uma análise das formas de representação do Brasil nas caricaturas, fazendo foco nas conotações culturais dessas representações e os movimentos políticos que alentaram o caricaturista a interpretar a realidade e traduzi-la visualmente dessa forma em particular.

Palavras chave: caricaturas, Buenos Aires, alteridade, conflito.

\footnotetext{
${ }^{1}$ Bacharel em História pela Universidade Federal da Integração Latino-Americana (UNILA) e mestranda do Programa de Pós-Graduação em Integração Contemporânea da América Latina na mesma universidade. Artigo que forma parte da trabalho de dissertação em andamento, intitulado (Des)construcción nacional y prensa ilustrada en el Río de la Plata: el caso de El Mosquito (Buenos Aires) y La Ortiga y el Garrote (Montevideo) a finales del siglo XIX. Correio electrónico: silvinasosav@gmail.com.
}

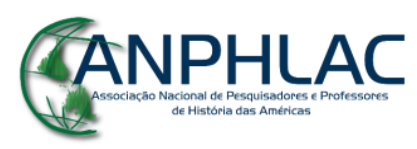

Revista Eletrônica da ANPHLAC, ISSN 1679-1061, №. 22, p. 118-146, Jan./Jun., 2017.

http://revista.anphlac.org.br 


\title{
Historical rivalries: the image of Brazil in the illustrated press from Buenos Aires by the end of $19^{\text {th }}$ century
}

\begin{abstract}
In Latin America, the last decades of the $19^{\text {th }}$ century were marked by the consolidation of National State. During this period, were strongly discussed the national identities on the symbolic plane. The international scene, will be extremely important to define this identities and it will be the main objective of this paper to think about this question from the imaginaries of Brazil in Argentina, starting from the hypothesis that Brazil was presented as the necessary otherness to allow Argentina form an image of itself. The illustrated press will be a space where the ideas and imaginaries will be powerfully present. El Mosquito, from Buenos Aires, one of the journals of political satire and critic, where the image occupied a central place, will be the principal source of this work. It pretends to analyze the ways of representation of Brazil in the caricatures, focusing on cultural implications and the political movements that encouraged the caricaturist to represent the reality and translate it on these particulars visual terms.
\end{abstract}

Key words: caricature, Buenos Aires, otherness, conflict.

Artigo recebido em: 10/10/2016

Artigo aprovado para publicação em: 20/12/2016

América Latina en el siglo XIX es un espacio de constantes conflictos y tensiones. Luego de siglos de dominación colonial y de un modo general - sobre todo para las regiones invadidas y dominadas por el Imperio Español - sus primeras décadas se caracterizarán por los fuertes enfrentamientos, militares y simbólicos, con la metrópoli por conseguir la "independencia". Más tarde, la configuración de nuevas entidades político territoriales suscitará nuevas tensiones: diferentes facciones entrarán en disputa por la imposición de modelos e ideas y las fronteras serán espacios en constante conflicto y transformación. Particularmente en los países de la Cuenca del Plata, las necesidades económicas y el afán de lucir como Estados "modernos" que se instala definitivamente a finales del mismo siglo, luego de la desmedida y sangrienta Guerra de la Triple Alianza, (1864-1870), se intentará reducir el enfrentamiento bélico entre los diferentes Estados emergentes y entre las diferentes facciones en disputa dentro de ellos. Sin embargo, está cuestión no reducirá el conflicto: reconfigurará y creará nuevas manifestaciones y diferentes escenarios de batalla.

La prensa será uno de estos espacios de enfrentamiento y exposición de los diferentes conflictos y desencuentros. (ÁLVAREZ, 2008) A través de la letra y de la

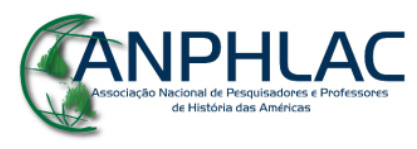

Revista Eletrônica da ANPHLAC, ISSN 1679-1061, №. 22, p. 118-146, Jan./Jun., 2017.

http://revista.anphlac.org.br 
imagen, las publicaciones periódicas, participarán en las batallas políticas y sociales configurándose como actores centrales de las mismas tanto dentro del propio Estado, como en el plano de las relaciones interestatales. Particularmente, un género de publicaciones tendrá gran impulso: la prensa ilustrada de sátira política, donde las imágenes caricaturales tendrán un rol esencial.

El presente trabajo pretende presentar y realizar reflexiones iniciales sobre un asunto que forma parte de un proyecto mayor titulado (Des)construcción nacional y prensa ilustrada en el Río de la Plata: el caso de El Mosquito (Buenos Aires) y La Ortiga y el Garrote (Montevideo) a finales del siglo XIX, el cual está siendo desarrollado dentro del Programa de Posgrado en Integración Contemporánea de América Latina de la Universidad Federal de la Integración Latinoamericana. Si bien el objetivo general del proyecto apunta a pensar sobre todo la construcción del Estado nacional y el papel de la región a partir de las imágenes de la prensa ilustrada en el Río de la Plata con base en un periódico montevideano y otro porteño, es pertinente entender las dinámicas de identidad y las relaciones con aquellos actores que no se localizan inmediatamente en este espacio, pero que han tenido una gran importancia para la conformación de las identidades regionales en ambos márgenes del Plata. Para ello, en las siguientes páginas, pensando desde el lado occidental del estuario platense, se abordará específicamente la forma en que Brasil es presentado en las caricaturas de la prensa ilustrada de Buenos Aires a partir del periódico El Mosquito. Entender la imagen como una narrativa visual (MANGUEL, 2001) y no apenas como una ilustración sobre un discurso textual se coloca como eje central a este trabajo, que procura acercarse a un abordaje cultural y visual sobre la historia sociopolítica en América Latina.

Durante el proceso de consolidación de los Estados nacionales - segunda mitad del siglo XIX - la promoción de una identidad pretendidamente nacional fue un objetivo de las nuevas configuraciones políticas que buscaban afirmarse simbólica y materialmente en territorio americano. Esa construcción identitaria será impulsada por el mismo Estado, a través de la educación, de la creación de infraestructura, de la divulgación de símbolos, etc., pero también será adoptada y alimentada por otros actores, entre ellos la prensa. Ésta, venía desarrollándose a grandes pasos en América Latina. Mencionando sucintamente algunos motivos, las condiciones políticas post "independentistas" y la propia configuración de los territorios como Estados,

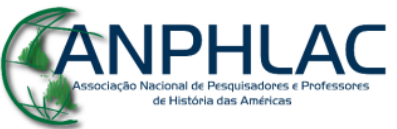

Revista Eletrônica da ANPHLAC, ISSN 1679-1061, №. 22, p. 118-146, Jan./Jun., 2017.

http://revista.anphlac.org.br 
propiciaron la proliferación de este medio de comunicación. Por otro lado, las innovaciones tecnológicas, posibilitaron una mayor reproducción material de las publicaciones que a su vez, fueron circuitos de distribución y consumo cada vez mayor. Dentro de este contexto, el objetivo de este escrito será el de analizar la forma en la que aparece la imagen de Brasil en la prensa ilustrada porteña ${ }^{2}$ a partir del periódico $E l$ Mosquito entre los años 1873 y 1874.

Alessandro Candeas afirma que "nada há de original em falar que as relações Brasil - Argentina foram erráticas durante grande parte da História" (CANDEAS, 2005, p. 178). Concretamente dentro de esa inestable forma de relacionarse entre estas entidades, en el marco temporal que se sitúa esta pesquisa, Argentina y Brasil se encontraban inmersos en una fuerte tensión por las negociaciones posteriores a la Guerra de la Triple Alianza que en un doble movimiento, se basarán y alimentarán la rivalidad histórica de ambos Estados en formación ${ }^{3}$, los cuales simultáneamente, se estaban construyendo simbólicamente a sí mismos, creando, en el mismo proceso, figuras de Alteridad. En este juego de aproximaciones y distancias, autoafirmaciones y construcciones del Otro, el recién citado Candeas considera que "a relação com o Brasil contém elementos estruturantes para a Argentina. Os laços bilaterais a induziram a se estruturar institucionalmente, como Estado; culturalmente, como nação sul-americana [...]” (2010, p. 144), enfatizando la dinámica entre ambas entidades políticas para la construcción de sí mismos. En otras palabras, la construcción de la idea de Argentina guarda una estrecha relación con la conformación de una idea estereotipada sobre otro: su vecino.

A partir de este juego de identidad-alteridad que se da de manera relacional es que surge la interrogante: ¿cómo El Mosquito configura visualmente a Brasil en sus

\footnotetext{
${ }^{2}$ Cabe destacar el carácter específicamente porteño de la publicación estudiada en este trabajo. En ningún momento podemos confundir el espacio de Buenos Aires y proyectarlo nacionalmente como la totalidad de Argentina. Esto sería un gran error, dada la diversidad de posicionamientos políticos y características distintas que presentaba el territorio que se entendía como Argentina.

${ }^{3}$ No es objetivo de este artículo agotar el histórico de las relaciones entre estos dos Estados que dio base a la rivalidad que se constata en el período estudiado. Sin embargo, apenas para situar se nombrarán algunos hitos que configuraron este tipo de relación. En primer lugar, la constitución de Argentina como República y Brasil como Imperio a comienzos del siglo XIX, fue un factor de desconfianza mutua. (DORATIOTO, 2008) El inicio de sus relaciones formales se dio en torno de la disputa por la Banda Oriental, que culminó con la renuncia obligada de posesión sobre aquel territorio y el surgimiento de un nuevo Estado: Oriental del Uruguay. Por último, durante la Guerra de la Triple Alianza se había conseguido un alineamiento estratégico entre ambos gobiernos, una aproximación que rápidamente se desgastará y se recrudecerán las tensiones y la rivalidad al terminar el conflicto bélico.
}

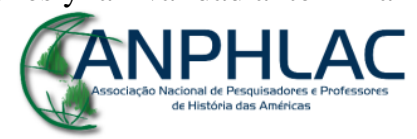

Revista Eletrônica da ANPHLAC, ISSN 1679-1061, №. 22, p. 118-146, Jan./Jun., 2017.

http://revista.anphlac.org.br 
caricaturas? ¿Qué connotaciones culturales tienen esas imágenes? ¿Qué movimientos políticos alientan al caricaturista a interpretar la realidad y plasmarla de esa manera en particular? Estas preguntas serán las que nortearán el trabajo a desarrollarse en las próximas páginas, cuya fuente principal de análisis serán las imágenes caricaturales que expresen algún aspecto de las relaciones entre la República y el Imperio en el período histórico establecido.

Las imágenes han sido fuentes poco valorizadas por muchos historiadores por largo tiempo, desconsiderando que su análisis es capaz de ofrecer un entendimiento más completo sobre las múltiples dimensiones de los procesos que se estudian. (KNAUSS, 2006) Si se considera que "se han utilizado imágenes (...) para construir y afianzar imaginarios políticos que permitan legitimar o cuestionar la sociedad existente" (PÉREZ VEJO, 2012), el estudio de las fuentes visuales se torna una pieza central para el entendimiento de ciertos aspectos políticos y culturales del tiempo pretérito.

Entendidas como fuentes históricas, las imágenes deben ser pensadas contextualmente. Un error en el que comúnmente se cae es en el de pensar que la imagen es una lenguaje universal capaz de ser entendido de igual manera a lo largo del tiempo. Las imágenes son siempre creadas en un contexto y dialogan con las habilidades de entenderlas e interpretarlas que los sujetos de la época tienen. Esto lleva a reflexionar sobre las limitaciones que un observador del siglo XXI puede tener al afrontarse a una caricatura del siglo XIX por el desconocimiento del código en el cual fue configurada la fuente. Sin embargo, esto no es un freno para la labor investigativa. Reconociendo las dificultades es que se realiza la tarea de interpretación con ayuda de otras fuentes e historiografía sobre la época que brindan elementos para la tarea hermenéutica.

En concordancia con lo anterior, el sociólogo británico Christie Davis define las caricaturas como "objetos visuais e materiais compostos por um indivíduo específico para um grupo específico de indivíduos e, geralmente, só podem circular se houver um meio físico de reprodução" (DAVIES apud LUSTOSA, 2011, p. 94). A partir de esta breve definición, se sustenta que la materialidad que tienen las imágenes que se estudiarán es esencial para el discurso contextual que platean las narrativas visuales. Así, el medio físico que las contiene debe ser objeto de reflexión.

\section{GANPHLAC}

Revista Eletrônica da ANPHLAC, ISSN 1679-1061, №. 22, p. 118-146, Jan./Jun., 2017.

http://revista.anphlac.org.br 
El periódico El Mosquito es el medio material que permitió la circulación de las imágenes que serán aquí tratadas. Esta publicación fue pensada y realizada desde Buenos Aires. Tuvo una periodicidad semanal y se extendió en el período que se comprende entre los años 1863 y 1893. Se autodefinía, desde su primera publicación como periódico satírico y burlesco y esta será la tónica de sus más de 1500 números. A través de sus caricaturas - protagonistas indiscutibles de la publicación - y de algunas secciones, como los Picotones, el periódico se dedicó a realizar fuertes críticas a la sociedad en la que se enmarcaba, principalmente en el plano político.

Este periódico es una de las primeras publicaciones periódicas de gran continuidad y alcance para la época, gozando de una gran popularidad ya desde sus primeros números. (SZIR, 2009; DE MARCO, 2006; SILVA, 2013) Este dato no es menor, dentro de un contexto en el cual muchas publicaciones rioplatenses tenían una duración muy breve. Algunas, nacían y morían en el período de un mes, otras, lograban sostenerse por algunos meses. (ÁLVAREZ, 2008) Era excepcional que un periódico se prolongara a través de los años de la manera que lo hizo El Mosquito durante tres décadas.

Su fundador y primer director, fue el litógrafo y dibujante francés Henry Meyer (1844-1899), quien será substituido por el también francés Henry Stein (1843-1919, quien más tarde españolizará su nombre a Enrique) en 1868, autor de las caricaturas analizadas en el presente trabajo. Tanto con Stein como con Meyer, la figura del director ilustrador ya muestra la jerarquía y la centralidad que las imágenes tendrán dentro de las normalmente cuatro páginas de hebdomadario. El Mosquito, será tributario de las revistas ilustradas francesas e inglesas de crítica política de gran popularidad en la época del otro lado del Atlántico ${ }^{4}$, adoptando referenciales visuales y formas Europeas que reconfigurará en términos locales.

En la época de circulación de El Mosquito, "la prensa fue uno de los escenarios donde se debatían las ideas políticas y se dejaban claro cuáles eran los valores sociales en juego" (FUNKELMAN; REITANO; RIBEIRO, 2006, p. 3). Particularmente puede pensarse que las publicaciones periódicas, aportaron, entre otras cosas, a la creación y difusión de una identidad/alteridad localizada. En este sentido, sobre la construcción de

\footnotetext{
${ }^{4}$ Desde los primeros números, El Mosquito "promete que sus páginas serán de la clase del Charivari de París y del Punch de Londres” (FUNKELMAN; REITANO; RIBEIRO, 2006, p. 4).

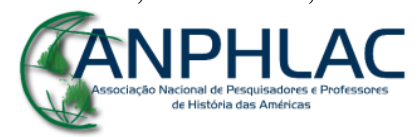

Revista Eletrônica da ANPHLAC, ISSN 1679-1061, №. 22, p. 118-146, Jan./Jun., 2017.

http://revista.anphlac.org.br
} 
una identidad colectiva, Bendicho y Sampaio (2010) advierten que ésta va de la mano con una proyección de relacionamiento con las alteridades. Por lo tanto, en el proceso de afirmación de lo propio se configuran agentes externos que le dan mayor nitidez al propio ser nacional que el periódico plantea a lo largo de sus narrativas visuales. En las imágenes analizadas, Brasil se coloca como esa alteridad y será objetivo de este trabajo entender en qué términos y con qué connotaciones Brasil es el Otro de Argentina. En palabras de los autores ya mencionados:

Inclusive o espaço internacional mostra-se como um lugar de constituição das identidades culturais, uma vez que elas também se forjam em função das relações entre as nações, isto é, no contato com o "outro". (BENDICHIO; SAMPAIO, 2010, p. 9)

Esas representaciones visuales, hechas desde ese particular lugar de enunciación, colocarán elementos que puedan ser identificables para el lector-observador del Buenos Aires de las últimas décadas del siglo XIX. Así, las narrativas propuestas por Stein en las páginas de El Mosquito, dialogarán estrechamente con el repertorio visual de su público, con el propio abanico de posibilidades que el caricaturista tiene y con la situación sociopolítica del momento que será el insumo principal que se tomará para las propuestas satírico burlescas de las caricaturas, a partir de las opciones técnicas que se presentan como posibles 5 . Sobre las tecnologías de impresión disponibles, Beretta García afirma que:

La litografía combinó las posibilidades artísticas y técnicas como forma de impresión económica seriada, contribuyendo a la difusión de las imágenes más allá de los círculos pudientes, para los cuales era más fácil la adquisición de pinturas, empapelados con escenas y paisajes, libros y grabados. (BERETTA GARCİA, 2012, p. 17)

Esta forma de impresión que permitió la reproducción y una expansión en la posibilidad de adquisición de imágenes a un nivel nunca antes visto (BENJAMIN, 2003, p. 39), no es un dato menor. En el siglo XIX, las posibilidades de ver y de poseer imágenes no se asemejan a la de los días de hoy. La investigadora Sandra Szir considera

\footnotetext{
${ }^{5}$ La técnica de impresión litográfica "basa su procedimiento en el empleo de materiales grasos como jabón y sebo. Dibujando con dichos materiales sobre la piedra, una vez humedecida, la tinta repartida sobre ella es repelida por la humedad, pero es retenida por los materiales grasos con los que se trazó el dibujo, procedimiento denominado adsorción. Colocando en la prensa la piedra entintada y sobre ella una hoja, se obtiene una o una serie de láminas impresas" (BERETTA GARCİA, 2012, p. 18).
}

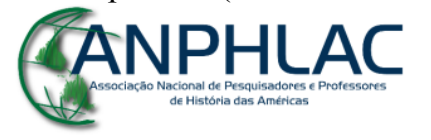

Revista Eletrônica da ANPHLAC, ISSN 1679-1061, №. 22, p. 118-146, Jan./Jun., 2017.

http://revista.anphlac.org.br 
que los periódicos ilustrados florecieron en la segunda mitad del XIX gracias - en parte - al desarrollo de esta técnica y, en consonancia con Beretta García, afirma que:

[...] satisfacían la curiosidad y el deseo de ver y poseer imágenes. Para muchos, las ilustraciones que los periódicos ponían en sus manos a un precio accesible, implicaba la primera posibilidad de acceder a representaciones de objetos, ciudades lejanas, personajes ilustres, eventos recientemente ocurridos, imágenes técnicas o científicas, imaginería patriótica. (SZIR, 2009, p. 1, cursivas nuestras)

Entre esas imágenes que El Mosquito posibilitó el acceso a un gran número de personas en la ciudad de Buenos Aires y alrededores, estaban las caricaturas sobre Brasil. Esta cuestión tendrá central importancia en un momento cultural en el cual las dinámicas de identidad/ alteridad se estaban disputando en un terreno simbólico y en un espacio histórico en el cual existían tensiones políticas con Brasil, conflicto en el cual las caricaturas de Stein tomarán partido de manera clara. Reírse de Brasil a partir de estas imágenes significaba un distanciamiento del mismo y una forma de ponerse por encima del vecino, afirmando la noción de un ego superior. Como se verá más adelante, estas imágenes - que por el hecho de ser satírico burlescas no son inocentes ni exentas de proyección política, sino más bien, todo lo contrario - se basarán en la rivalidad existente entre Brasil y Argentina y la alimentarán, consolidando imaginarios desde una concepción republicana y racista.

Estas imágenes recurrirán al uso de los estereotipos, entendidos como un mensaje ultra simplificado sobre determinado asunto. (ZINK apud LUSTOSA, 2011) Así, algunos elementos son destacados de manera fácilmente reconocible y se convierten en la marca identificable de un personaje, situación o lugar. El lápiz litográfico de Enrique Stein recurrirá a elementos puntuales de la sociedad brasileña para configurar una imagen reconocible del Imperio vecino que se repetirá en diferentes imágenes.

\section{GANPHLAC}

Revista Eletrônica da ANPHLAC, ISSN 1679-1061, №. 22, p. 118-146, Jan./Jun., 2017.

http://revista.anphlac.org.br 


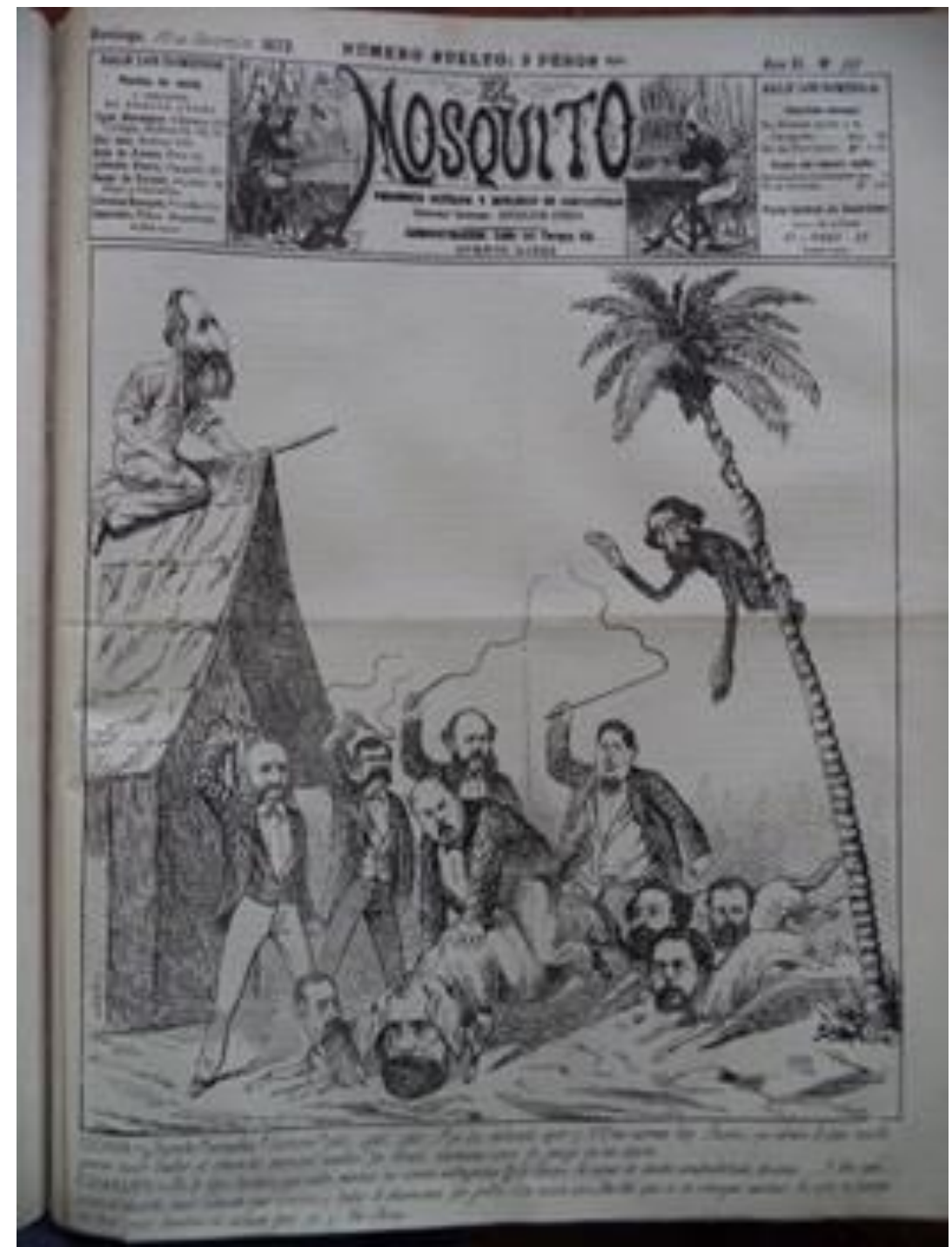

Imagen 1 - El Mosquito, Nro. 569, 30 de noviembre de 1873

En la Imagen 1 es posible observar una escena donde están representados varios políticos de la República Argentina y algunos de ellos adquieren características zoomórficas. En la parte inferior de la caricatura se puede identificar un sujeto con cuerpo de chancho siendo montado por un hombre, rodeado por un grupo de individuos con látigos en sus manos y otros cuatro sujetos con el rostro de algunos políticos y cuerpo de felinos. Hacia la derecha y en un nivel superior al grupo de personas recién mencionado, se encuentra una alta palmera que tiene un mono con rostro de hombre colgado.

La forma animal que adoptan algunos cuerpos en las caricaturas es un recurso que el dibujante tiene para deshumanizar al sujeto representado a través de la risa que

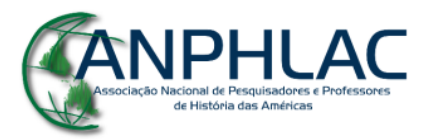

Revista Eletrônica da ANPHLAC, ISSN 1679-1061, №. 22, p. 118-146, Jan./Jun., 2017.

http://revista.anphlac.org.br 
generaría en el observador de esa imagen. Así, el relacionar individuos específicos con determinados animales, que muchas veces tienen formas convencionales de entenderse asociadas a valores específicos, refuerza un determinado mensaje que se encuentra por detrás de la imagen.

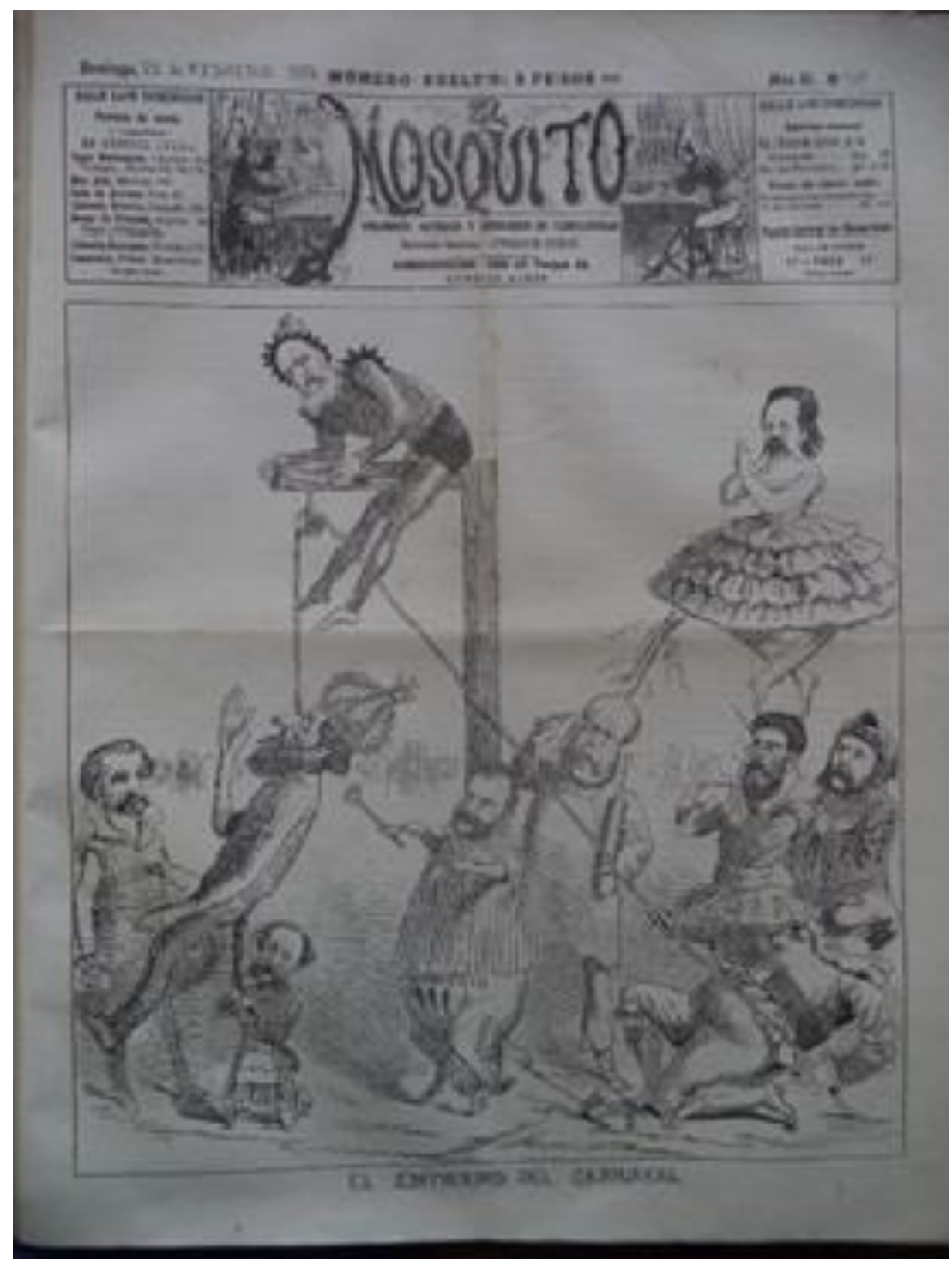

Imagen 2 - El Mosquito, Nro. 581, 22 de febrero de 1874

A efectos del presente trabajo, interesa la forma en la que es presentado el sujeto que se encuentra colgado en la palmera con cuerpo de mono. Esta representación la vemos también en otras imágenes como la 2 y la 3: el mismo individuo en particular tiene cuerpo de mono y en estas últimas dos imágenes está usando, además, una corona.

\section{GANPHLAC}

Revista Eletrônica da ANPHLAC, ISSN 1679-1061, №. 22, p. 118-146, Jan./Jun., 2017.

http://revista.anphlac.org.br 


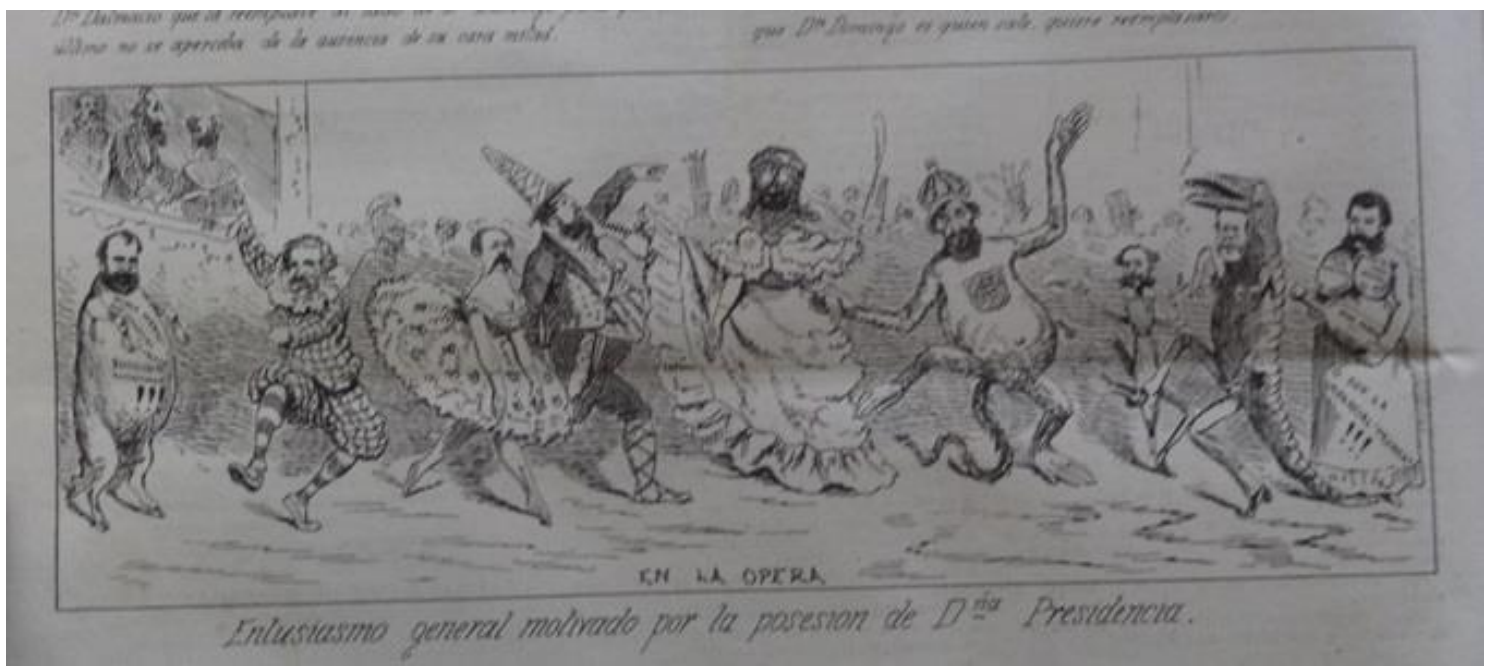

Imagen 3 - El Mosquito, Nro. 580, 15 de febrero de 1874

Este sujeto es Bartolomé Mitre (1821-1906), en ese entonces ex presidente (1862-1868) de la República Argentina y uno de los blancos de ataques predilectos de El Mosquito desde sus comienzos. Su nariz alargada y pronunciada, su barba prominente, su cabello medianamente largo y su delgadez, son las características que las caricaturas exageran y explotan para la configuración de un cuerpo reconocible ${ }^{6}$.

Dado que el primer número de la publicación coincide con el segundo año de la presidencia de Mitre - 1863 -, éste siempre había sido uno de los sujetos favoritos para la crítica y la burla. La forma de presentar a este político en particular varió conforme las acciones que se estuvieran llevando adelante en el contexto en el cual cada caricatura aparecía y circulaba. Así, Mitre fue caracterizado de manera femenina, como miembro de un circo, como personaje urbano asociado al espacio de Buenos Aires ${ }^{7}$, entre otras formas que su cuerpo adoptó a lo largo de los diferentes números de la publicación. Su protagonismo en la parte textual de las páginas también le valió un apodo jocoso:

\footnotetext{
${ }^{6}$ Vale recordar la forma en que Daniel Álvarez define caricatura: "El dibujo humorístico o caricatura (que viene del italiano 'caricare' cuyo origen etimológico es 'cargar, exagerar') es una ilustración que exagera o distorsiona la esencia básica de una persona o cosa para crear un parecido fácilmente identificable, aunque de forma que cause comicidad. Suele ser un retrato, u otra representación humorística que exagera rasgos físicos (gordo, flaco, alto, bajo) o faciales (labios, cejas, cabeza) con el fin de producir un efecto grotesco [...]" (2008, p. 369)

${ }^{7}$ En contraposición a Justo José de Urquiza, federalista, enemigo político de Mitre y siempre asociado por El Mosquito a un espacio de provincia ajeno a la ciudad portuaria, específicamente a la provincia de Entre Ríos. Las caricaturas del periódico transmitían este mensaje a partir de las vestimentas de gaucho que siempre eran colocadas en el cuerpo de Urquiza confrontado siempre con un Mitre de traje.
}

\section{GANPHLAC}

Revista Eletrônica da ANPHLAC, ISSN 1679-1061, №. 22, p. 118-146, Jan./Jun., 2017.

http://revista.anphlac.org.br 
"Bartolo". Particularmente, dentro del recorte temporal de este trabajo, llama la atención la constante reiteración de la representación de Mitre como un mono con corona.

Estas características que toma el cuerpo del ex presidente, configuran una forma de percibir y deslegitimar al Imperio de Brasil y a la vez, una postura respecto a las acciones que Mitre estaría realizando. Como ya fue mencionado, estas imágenes fueron producidas en un contexto de negociaciones que siguieron a la Guerra de la Triple Alianza, momento en el cual las relaciones entre los gobiernos de Argentina y Brasil estaban tensos ${ }^{8}$. En el año 1873, el entonces presidente Domingo Sarmiento (18111888) - otro de los personajes reiteradamente caricaturizados por El Mosquito -, recomendó a Mitre la misión de negociar ante la corte en Río de Janeiro determinados litigios territoriales que siguieron al fin del conflicto armado.

\begin{abstract}
En la capital carioca, Mitre firmó con el marqués de San Vicente un convenio que dejaba nuevamente en vigor el tratado de la Triple Alianza, pero respetando los tratados Cotegipe-Lóizaga como un hecho consumado. Como fruto de sus conversaciones con San Vicente, Mitre llegó a un acuerdo el 19 de noviembre de 1872, por el cual la Argentina reclamaba ante Paraguay la línea del Pilcomayo -más una franja del territorio que incluyera Villa Occidental-, y renunciaba al Chaco Boreal -que pasaría a arbitraje-. Pero por un grave error diplomático de Mitre, este acuerdo con el diplomático brasileño no fue establecido por escrito. Esta actitud flexible de Mitre le valió roces con el nuevo canciller de Sarmiento y sucesor de Varela, Carlos Tejedor, quien no aceptaba la renuncia al Chaco a cambio de una alianza argentino-brasileña. (ESCUDÉ; CISNEROS, 2000)
\end{abstract}

La cita precedente coloca que el resultado de las conversaciones con representantes del gobierno imperial brasileño y encabezadas por Mitre, no obtuvieron la aprobación unánime por parte de sus coterráneos. Entre los disconformes, parece encontrarse los sujetos responsables por la publicación de El Mosquito, específicamente Enrique Stein por ser el autor de las caricaturas recién presentadas y editor responsable del periódico. En ellas, el "Mitre mono con corona" es un recurso que transmite la idea de un representante argentino asociado más al adversario político que a la sociedad que debería estar representando, entendiendo que el mono con corona es una metáfora visual racista de lo que sería el Imperio de Brasil, provocado en parte por permanencia del sistema esclavista hasta 1888.

\footnotetext{
${ }^{8}$ Candeas (2005) caracteriza a este período en particular como de inestabilidad estructural con predominio de rivalidad.
}

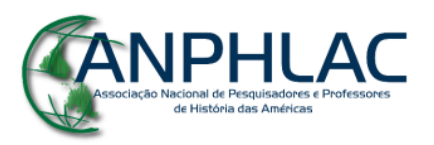

Revista Eletrônica da ANPHLAC, ISSN 1679-1061, №. 22, p. 118-146, Jan./Jun., 2017.

http://revista.anphlac.org.br 
Del lado argentino, la esclavitud había sido abolida constitucionalmente en el año $1853^{9}$ y tenía como antecedente la ley de "libertad de vientres" de 1813, momento en el cual se estableció que todos los esclavos provenientes de otras regiones al ingresar a territorio argentino, serían libres. Con treinta y cinco años de diferencia, hacia finales de siglo, junto con el derrumbe del sistema imperial y la llegada de la República a Brasil, se "termina" el sistema esclavista. Pero en ese período de tiempo que separa esos dos procesos en estos territorios, Argentina - y otras repúblicas en formación criticaran y verán la esclavitud en Brasil como un "atraso", que sumado a su sistema monárquico, se entenderá como un espacio "anti-moderno", lo que contribuye a la formación de un Brasil como una alteridad de Argentina que buscaba afirmarse en base a los pilares de la civilización y lo moderno ${ }^{10}$.

La invisibilización y negación del sujeto negro en la sociedad argentina ${ }^{11}$, se afirmaba en la contraposición con la fuerte presencia de sujetos esclavizados negros en su vecino Brasil. Por este motivo, miradas desde Buenos Aires destacarán la cuestión racial, la fuerte presencia de negros en el país contiguo, tal y como hace Domingo Sarmiento en su obra Conflictos y armonías de las razas en América, publicado en $1883^{12}$. En esta obra, al tratar sobre la "raza negra", Sarmiento realiza una comparación entre la presencia negra en Brasil y en Argentina en la época contemporánea a la publicación, desde una perspectiva evolucionista, lo cual genera una visión negativa

\footnotetext{
${ }^{9}$ Artículo 15 de la Constitución de 1853: "En la Nación Argentina no hay esclavos: los pocos que hoy existen quedan libres desde la jura de esta Constitución; y una ley especial reglará las indemnizaciones a que dé lugar esta declaración. Todo contrato de compra y venta de personas es un crimen de que serán responsables los que lo celebrasen, y el escribano o funcionario que lo autorice. Y los esclavos que de cualquier modo se introduzcan quedan libres por el solo hecho de pisar el territorio de la República", disponible en <http://www.biblioteca.jus.gov.ar/constitucionargentina1853.html>, acceso en 06 jul. 2016.

${ }^{10}$ La Lei do Ventre Livre en Brasil del 27 de mayo de 1871, propuesta por el gabinete conservador presidido por el vizconde de Rio Branco fue impulsada en parte, bajo la justificativa de "mejorar" la imagen que Brasil tenía frente a los demás países por mantener el sistema esclavista. Texto competo en < http://www.direitoshumanos.usp.br/index.php/Documentos-Hist\%C3\%B3ricos-Brasileiros/lei-do-ventrelivre.html>, acceso en 08 jul. 2016.

${ }^{11}$ Prueba de ello es la negación que hace Sarmiento de los individuos negros en Argentina, como se puede ver en el siguiente pasaje: "Quedan pocos jóvenes de color, los cuales ocupan el servicio como cocheros de tono, como porteros de oficinas públicas y otros empleos lucrativos; pero como raza, como elemento social, no son ya un accidente pasajero, habiendo desaparecido del todo de las provincias, y no habiendo podido establecerse fuera de la ciudad" (SARMIENTO, 1883, p. 46).

${ }^{12}$ Sarmiento también tenía motivos políticos para subordinar socialmente a la población negra de Argentina. Su gran enemigo político, Juan Manuel de Rosas (1793-1877) había contado con gran apoyo de este grupo social en su gobierno (1829-1852). (YAO, 2015) Rosas representaba para Sarmiento la tiranía y la barbarie, factor esencial del "atraso" que viviría el país cuando realiza un diagnóstico sociopolítico de Argentina en Facundo o civilización y barbarie en las pampas argentinas (1845), publicación que se hace en Chile durante el exilio político de quien luego se tornaría presidente en 1868.
}

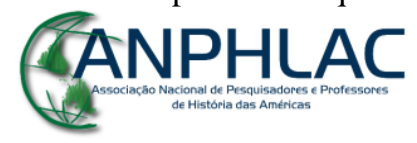

Revista Eletrônica da ANPHLAC, ISSN 1679-1061, №. 22, p. 118-146, Jan./Jun., 2017.

http://revista.anphlac.org.br 
sobre la presencia negra en la sociedad en general y en Brasil en particular. En ese sentido, el ya citado Candeas coloca que, hacia inicios de los 80 , pero entendiendo la presencia de ese pensamiento desde un tiempo anterior, Brasil era visto "como inferior nas esferas cultural e étnica" (2005, p. 9).

De esta manera, el mono se convertirá en un símbolo peyorativo que referirá a la población negra. Con este recurso visual, El Mosquito inferiorizará al Imperio de Brasil a partir de estas formas racistas que serán acompañadas de elementos de la naturaleza, como en el caso de la palmera de la Imagen 1, que oponen a este grupo a los ideales de civilización y modernidad con los que se auto-identificaba Buenos Aires desde la óptica evolucionista vigente en ese entonces.

La palmera, además de colocarse como medio para enfatizar "lo natural brasileño" forma parte también del repertorio visual reconocible en el siglo XIX para representar la idea de Brasil, tanto desde "adentro" como desde "afuera", a pesar de esta especie no ser originaria del continente americano ${ }^{13}$. La naturaleza, muchas veces es colocada en el lado opuesto en relación a la civilización. De esta manera, representar Brasil con elementos de la naturaleza, como este árbol refuerza un mensaje inferiorizante.

El otro elemento adjunto al cuerpo de Mitre es la corona. Este recurso visual, es una asociación directa al carácter monárquico del gobierno del Estado vecino, factor de diferenciación política. La convivencia con un estado monárquico se entendía como fuente de desconfianzas, puesto que desde 1810 - e incluso antes - se daba un esfuerzo material y simbólico de romper con aquellas formas que remitiesen a la época colonial, la cual fue cubierta con un velo de obscurantismo. Brasil, había optado por una continuidad ibérica, adoptando una forma de gobierno imperial y monárquica. Al respecto de este asunto, Candeas explica que:

\footnotetext{
Ao não romper com o sistema monárquico, contrastando com um hemisfério republicano, o Brasil foi percebido como herdeiro da aspiração hegemônica $e$ intervencionista portuguesa no Prata. (CANDEAS, 2005, p. 5, cursivas nuestras)
}

\footnotetext{
${ }^{13}$ Para ilustrar este punto, vale recordar la carta donde el pintor Manuel de Araújo Porto Alegre (18061879), recomienda a Victor Meirelles (1832-1903) colocar estos árboles en la composición de su famosa Primeira Missa no Brasil del año 1860 para hacerla reconociblemente brasileña a ojos de los observadores de los salones europeos donde la pintura debía ser expuesta.
}

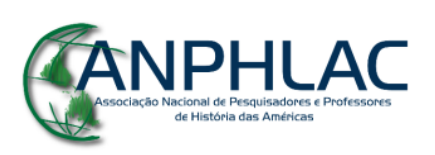

Revista Eletrônica da ANPHLAC, ISSN 1679-1061, №. 22, p. 118-146, Jan./Jun., 2017.

http://revista.anphlac.org.br 


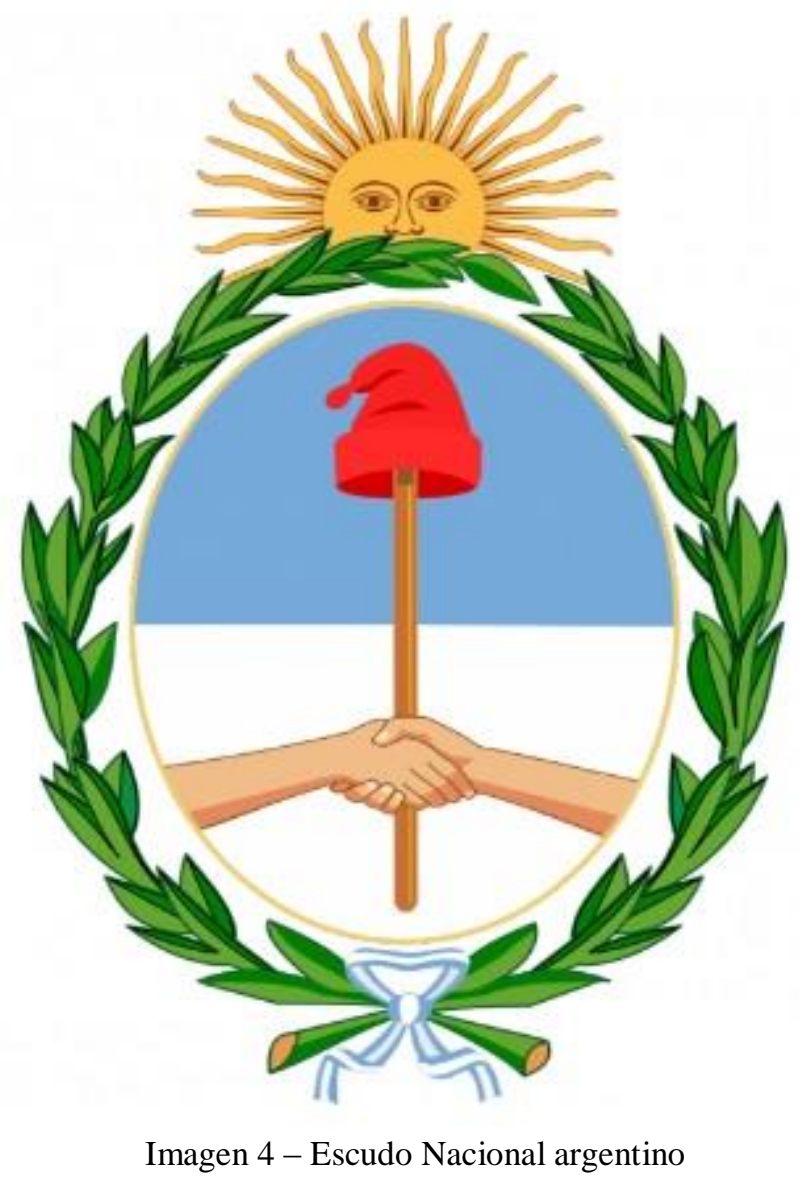

Desde comienzos del siglo, Argentina realiza esfuerzos materiales y simbólicos por afirmarse en cuanto República, entendida como una forma política de gobierno más moderna que la monarquía. En un plano visual, la utilización de elementos que remiten a la iconografía de la Revolución Francesa de 1789, entendida como vencedora de la monarquía e inspiradora del espíritu republicano, será un camino para la realización de este objetivo. Por ejemplo, desde una configuración visual oficial, se puede apreciar esto en el propio escudo nacional (Imagen 4) vigente desde la segunda década del siglo XIX. En el centro de esta imagen se encuentra un gorro frigio, símbolo de la revolución, la república y la libertad.

\section{GANPHLAC}

Revista Eletrônica da ANPHLAC, ISSN 1679-1061, №. 22, p. 118-146, Jan./Jun., 2017.

http://revista.anphlac.org.br 


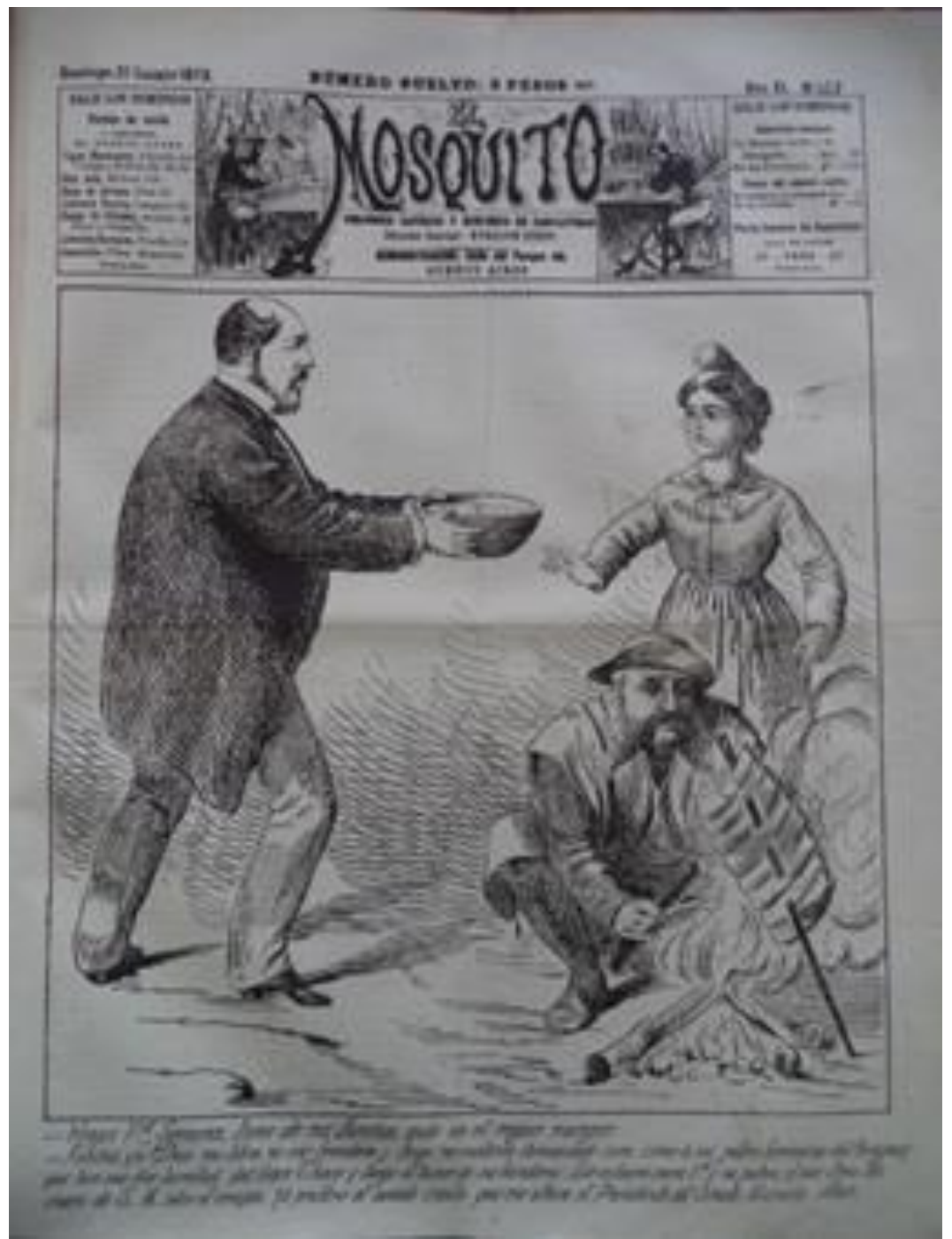

Imagen 5 - El Mosquito, Nro. 559, 21 de septiembre de 1873

- Venga Ud., señora, tome de mi fariña que es el mejor manjar.

- Fariña, yo! Dios me libre, no soy brasilera y luego me costaría demasiado caro, como a mi pobre hermano del Paraguay que tuvo que dar la mitad del Chaco y luego el honor de su bandera. Eso es bueno para Ud. y su patrón, el que lleva las cruces de S.M. sobre el corazón. Yo prefiero el asado criollo que me ofrece el presidente del Comité Alsinista.

El Mosquito servirá también como vehículo de esta afirmación política republicana. En la Imagen 5, se puede apreciar una especie de Marianne ${ }^{14}$ apropiada en términos gauchescos ${ }^{15}$ y entendida como alegoría de la República Argentina por el

\footnotetext{
${ }^{14}$ La Marianne es la figura alegórica que simbolizaría la República Francesa y tiene una larga tradición iconográfica donde su cuerpo y su presencia es asociada a la idea de lo nacional.

${ }^{15}$ En otras investigaciones realizadas a partir de El Mosquito, se ha reflexionado sobre la utilización de una estética gauchesca en la configuración de ciertos personajes. Se ha podido apreciar que cuando la
}

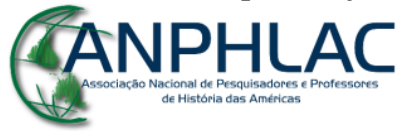

Revista Eletrônica da ANPHLAC, ISSN 1679-1061, №. 22, p. 118-146, Jan./Jun., 2017.

http://revista.anphlac.org.br 
rótulo que lleva en su pecho. En la situación que plantea esta narrativa visual se puede identificar un hombre que le ofrece a una mujer fariña para comer, alimento que ésta rechaza. El diálogo colocado por debajo de la imagen, brinda los motivos por los cuales ésta mujer no aceptaría el ofrecimiento: "Dios me libre, no soy brasilera".

Esta caricatura, niega y se aleja en el diálogo de Brasil, pero sobre todo afirma la idea de Argentina en la imagen. La mujer en esta escena se encuentra acompañada de un hombre vestido como un gaucho realizando un asado. Esta mujer alegoría de Republica funcionaría como una afirmación identitaria que va de la mano con el distanciamiento de la alteridad. La República-mujer-alegoría no come fariña, come asado y lo hace por motivos políticos. De esta manera, Brasil se afirma como una alteridad dentro de la narrativa propuesta, alteridad que en algunos casos se ubicará dentro de la propia Argentina para denunciar a quienes no estarían defendiendo los intereses nacionales, como es el caso de la representación de Bartolomé Mitre.

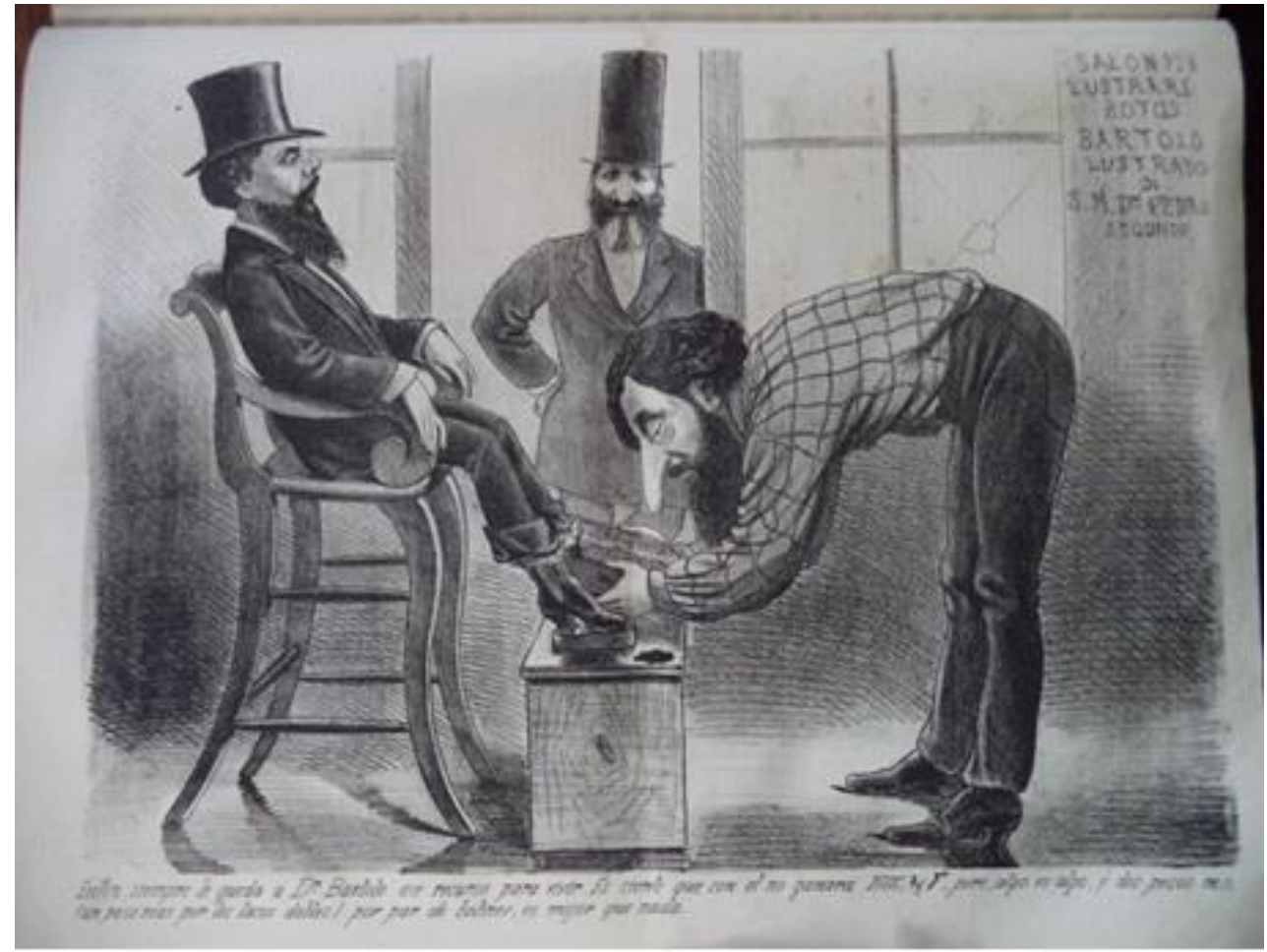

Imagen 6 - El Mosquito, Nro. 592, 10 de mayo de 1874

narrativa visual que se propone en la caricatura trata sobre un asunto de escala internacional (como en este caso) lo gauchesco es una forma reconocible de lo que es Argentina. No obstante, cuando la escala de representación es nacional, lo gauchesco asume una connotación negativa, es asociada con un espacio de provincia y se le imprime connotaciones peyorativas, en oposición a una estética urbana que representaría a Buenos Aires (como en el caso comentado en la nota 4 entre Urquiza y Mitre), explotando esa dicotomía sarmientina de civilización y barbarie.

\section{GANPHLAC}

Revista Eletrônica da ANPHLAC, ISSN 1679-1061, №. 22, p. 118-146, Jan./Jun., 2017.

http://revista.anphlac.org.br 


\section{SALON PER LUSTRARE BOTAS. BARTOLO LUSTRADOR DE S.M. $D^{m}$. PEDRO SEGUNDO.}

Enfin, siempre le queda a $D^{m}$. Bartolo ese recurso para vivir. Es cierto que con el no ganará $16662 / 3 \mathrm{~F}$, pero, algo es algo, y dos pesos m.c., (un peso más por los tacos dobles) por par de botines, es mejor que nada.

Esta idea de "traición" de Mitre, se repite nuevamente en la Imagen 6. En esta caricatura se puede observar al ex presidente lustrándole los zapatos a Nicolás Avellaneda (1837-1885), con quien en abril de 1874 se disputaría y perdería las elecciones presidenciales. Mitre está colocado en una situación de subordinación ante el pequeño cuerpo con el que usualmente la lápiz litográfico de Stein retrata a Avellaneda, prestando un servicio manual. Pero, lo más interesante de esta caricatura - para los objetivos del presente trabajo - , no es solo la relación jerárquica entre los personajes, sino la inscripción que se coloca en el muro del local: "Salon per lustrare botas. Bartolo lustrador de S. M. D ${ }^{\mathrm{m}}$. Pedro Segundo".

Una vez más, se reafirma la denuncia de que Mitre actuaría al servicio de Brasil. Estaría desarrollando su trabajo de lustrador ante de Su Majestad y el desarrollo de esta labor, implica que el cuerpo de quien lo desarrolla se tenga que inclinar necesariamente ante quien recibe el servicio, cuestión que es posible observar en la dinámica presentada entre Mitre y Avellaneda, pero que puede transponerse a la relación entre Mitre y Don Pedro II por la inscripción en la pared. Esta gestualidad corporal indica no solo una jerarquía de los sujetos, sino una relación en la cual una de las partes ordena y la otra ejecuta.

La leyenda de imagen coloca que Mitre realizaría esta tarea debido a su necesidad imperiosa por sobrevivir. Se entiende que esta metáfora no apuntaría apenas a una subsistencia material, sino también a una permanencia en el sistema político que está condicionado a la subordinación jerárquica en relación a los sujetos de cargos superiores. En el caso puntual de la caricatura mencionada, la reciente derrota electoral con Avellaneda, lo colocaría en una posición inferior, en la cual - por los gestos de su cara - no parece encontrarse conforme. Públicamente, de manera sistemática estaría al servicio del emperador vecino

\section{GANPHLAC}

Revista Eletrônica da ANPHLAC, ISSN 1679-1061, №. 22, p. 118-146, Jan./Jun., 2017.

http://revista.anphlac.org.br 


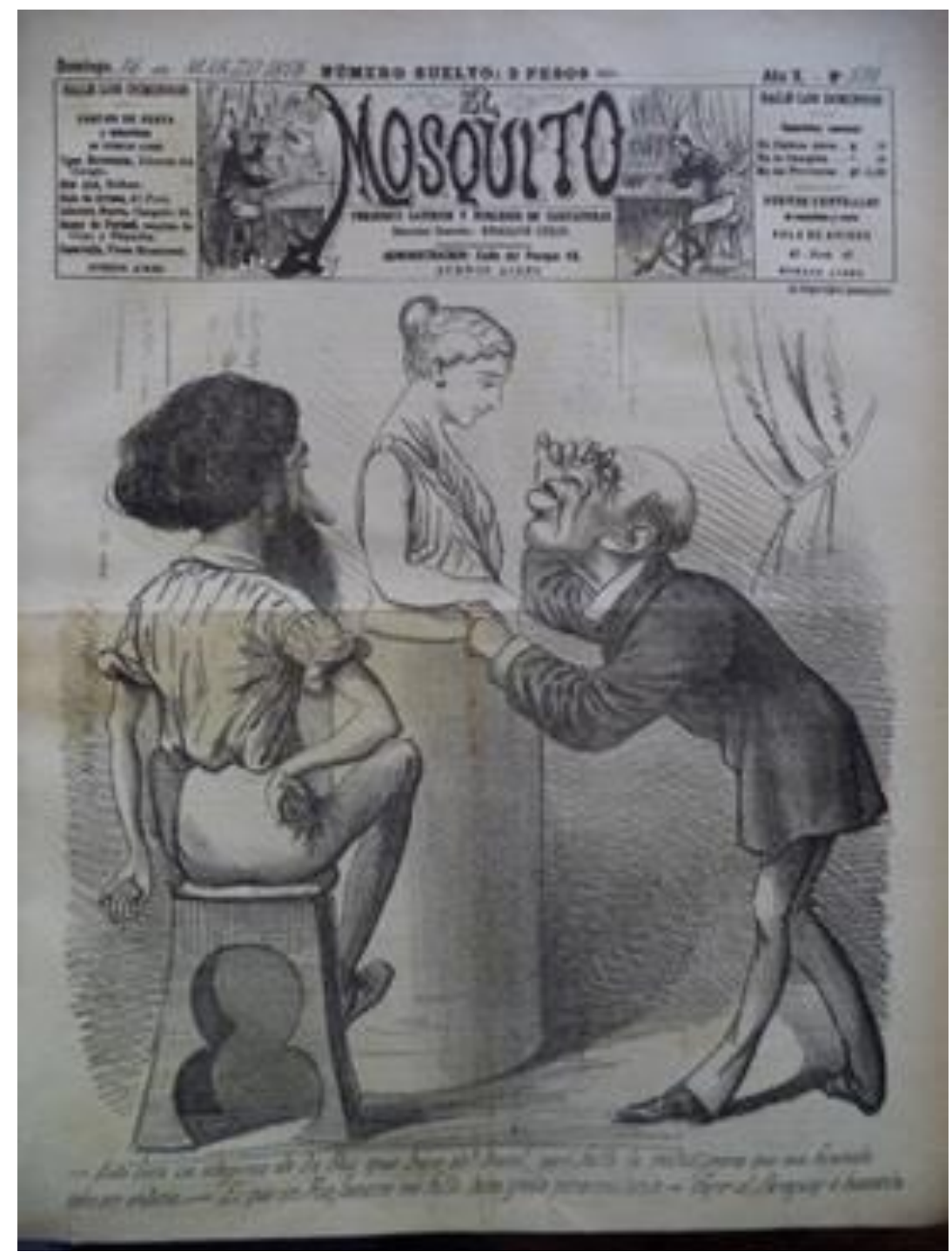

Imagen 7 - El Mosquito, Nro. 533, 16 de marzo de 1873

- Está bien su alegoría de la Paz que trajo del brazil, pero falta la mitad; para que sea fecunda debe ser entera.

- Es que en Rio de Janeiro me falto tiera greda para concluirla.

- Vaya al Paraguay a buscarla.

Por otro lado, la Imagen 7, coloca que la misión diplomática del ex presidente en Brasil, habría sido estimulada por su sucesor, Sarmiento. En esta narrativa, Mitre asume el personaje de un escultor (nuevamente se lo puede encontrar en una labor manual) y Sarmiento es quien encomienda la escultura. Esta escultura, busto de una mujer, sería una alegoría de la paz y, por el diálogo que acompaña la imagen, ésta habría sido traída

\section{GANPHLAC}

Revista Eletrônica da ANPHLAC, ISSN 1679-1061, №. 22, p. 118-146, Jan./Jun., 2017.

http://revista.anphlac.org.br 
desde Brasil, pero estaría incompleta. Por este motivo, Sarmiento le ordena terminar la "obra" en Paraguay.

La Imagen 7 permite pensar que si bien la guerra convencionalmente se entiende que finalizó con la muerte del Mariscal Francisco Solano López (1826-1870) en el Combate de Cerro Corá de 1870, no sería percibido de esta manera por los contemporáneos a estos acontecimientos, ya que vemos, que 3 años después de estos hechos El Mosquito publica una caricatura indicando que la paz estaría "incompleta".

Así, las tensiones que las negociaciones post conflicto generaran se entenderían todavía como una amenaza, como una continuidad del conflicto anterior con nuevos escenarios. En este sentido, Moniz Bandeira (2010) coloca que la década de 1870 a 1880 estuvo marcada por la posibilidad de enfrentamiento entre Brasil y Argentina, por lo tanto, la sensación de amenaza en relación a Brasil por parte de El Mosquito se hará manifiesta en imágenes como esta.

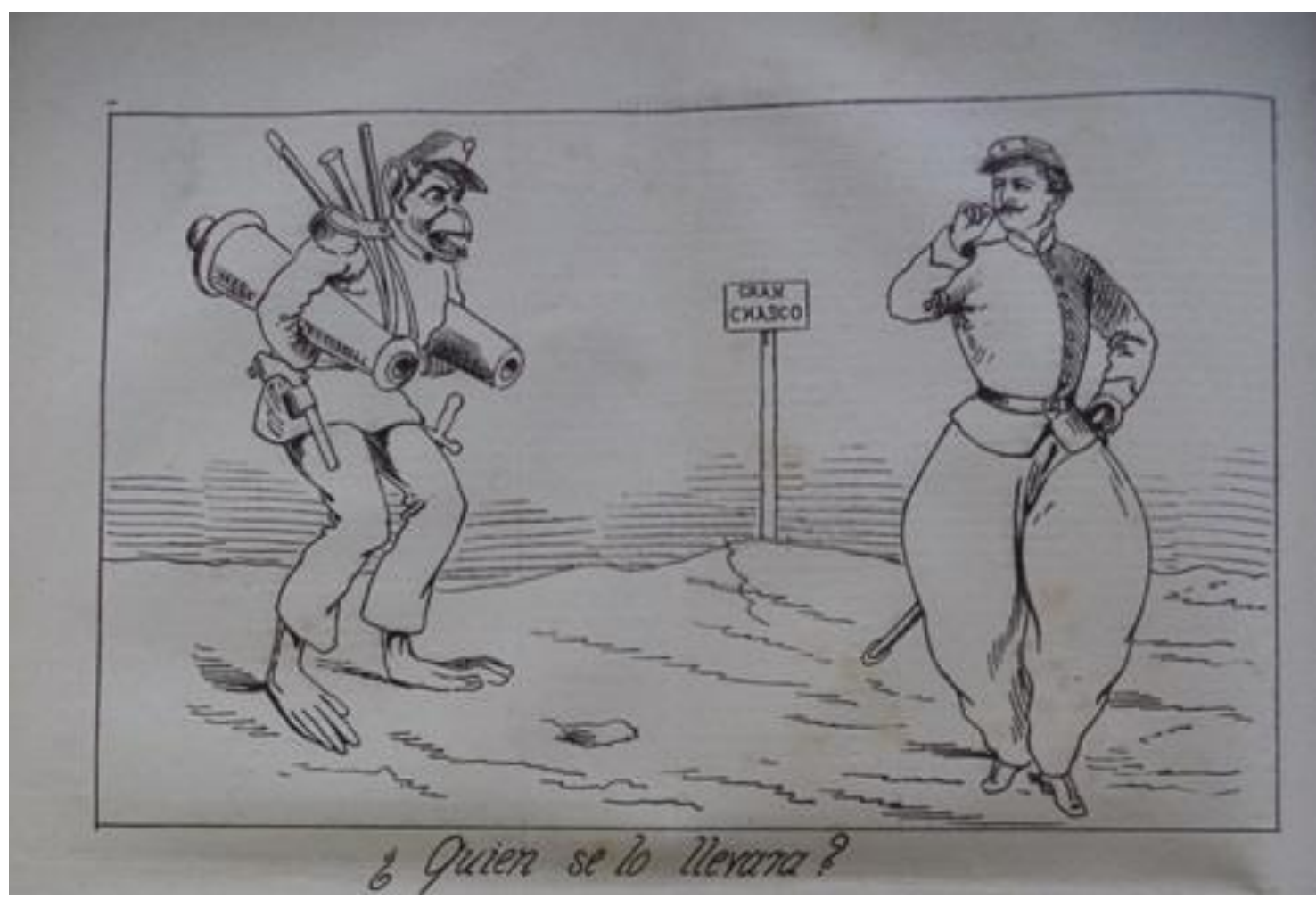

Imagen 8 - El Mosquito, Nro. 560, 28 de septiembre de 1873 GRAN CHASCO

¿Quién se lo llevará?

\section{GANPHLAC}

Revista Eletrônica da ANPHLAC, ISSN 1679-1061, №. 22, p. 118-146, Jan./Jun., 2017.

http://revista.anphlac.org.br 
Dichas negociaciones también son objeto caricaturizable por parte de Stein. La Imagen 8, lanza una pregunta sobre uno de los territorios en litigio, al cual El Mosquito se refiere como el "Gran Chasco”, en alusión al Chaco: “QQuién se lo llevará?”. Es interesante notar la representación de uno de los dos personajes que componen la escena: a la izquierda se puede apreciar un mono de traje militar con armamento de guerra y descalzo. Nuevamente, se identifica a este sujeto como Brasil en una clave racista y se hace manifiesto el sentimiento de amenaza bélica que la zona del Chaco suscitaría $^{16}$, puesto que el Otro en esta tensión post guerra - Brasil - está armado y pronto para atacar. Para la configuración visual del vecino, es importante hacer notar nuevamente, que el mono cuyo cuerpo se convierte en símbolo racista del Imperio, está descalzo. La representación de sujetos descalzos tiene una larga tradición iconográfica de asociación con la esclavitud, ya que los hombres, mujeres y niños esclavizados no utilizaban calzado.

\footnotetext{
${ }^{16}$ Doratioto (2014) coloca que el problema diplomático en torno a la posesión de la zona del Chaco, tiene origen en 1869, al instalarse un norteamericano en esta región para la explotación de madera quien rechazó pagar impuestos a las autoridades paraguayas, alegando, en base al Tratado de la Triple Alianza, que ese territorio sería argentino. Brasil no veía con buenos ojos que Argentina limitara a la vez con Asunción y Mato Grosso y este episodio desencadenó una serie de disputas diplomáticas en torno al derecho de posesión sobre la región.
}

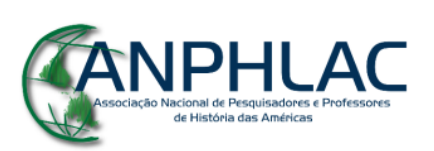

Revista Eletrônica da ANPHLAC, ISSN 1679-1061, №. 22, p. 118-146, Jan./Jun., 2017.

http://revista.anphlac.org.br 


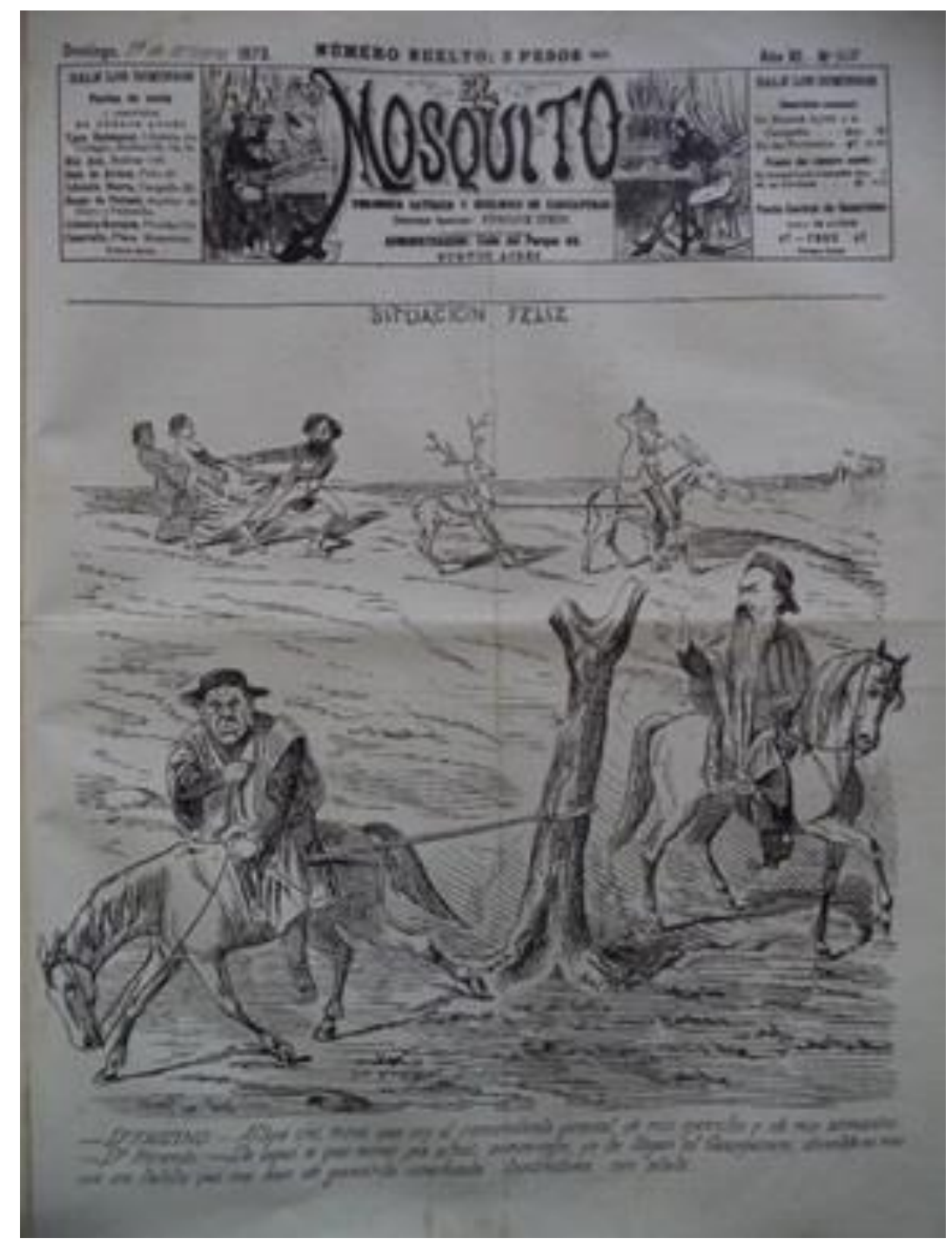

Imagen 9 - El Mosquito, Nro. 563, 19 de octubre de 1873

Las vicisitudes de los litigios territoriales post Guerra de la Triple Alianza, son puestas en discusión con un tono de denuncia por parte de El Mosquito, en la Imagen 9. Aquí se identifica en un primer plano, el cuerpo del entonces presidente Sarmiento en un caballo, siendo advertido por un sujeto (que hasta entonces no se ha conseguido identificar) sobre las situaciones que estarían aconteciendo a sus espaldas. En ese sentido, en el segundo plano de la imagen se ve al mono con corona - Brasil - montado en una mula identificada como Paraguay, en dirección a Río de Janeiro. La mula está cinchando con una cuerda un venado con el rótulo "Gran Chaco" y por detrás de ellos, se encuentra Mitre, nuevamente, llevando en la misma dirección a dos mujeres identificadas como Entre Ríos y Corrientes. Otra vez se repite el esquema del ex

\section{GANPHLAC}

Revista Eletrônica da ANPHLAC, ISSN 1679-1061, №. 22, p. 118-146, Jan./Jun., 2017.

http://revista.anphlac.org.br 
presidente traicionando a la Argentina en su misión diplomática, pero en este caso se agrega la idea de la dependencia en la conducción de Paraguay, siendo realizada por Brasil y también el problema en torno a la cuestión limítrofe. Se ve, que no solo Brasil se estaría llevando la región del Chaco - disputada por Argentina - sino que también esa "pérdida" comprometería a las provincias de Entre Ríos y Corrientes y por consecuencia, el control en torno a la navegación de la Cuenca del Plata, objetivo geopolítico de los dos Estados rivales.

El Mosquito denuncia, de esta manera, la indiferencia con la cual el presidente de la República -Sarmiento - trataría a este asunto y nuevamente, coloca a Brasil como una amenaza para la soberanía territorial de los territorios que Argentina defendería para si en las negociaciones post conflicto.

Por primera vez, dentro del cuerpo de imágenes seleccionadas, se puede ver una representación visual directa de Paraguay. No se puede dejar pasar que la forma que Stein decidió corporificar al gran vencido de la guerra, fue como una mula, animal estéril. La esterilidad de este animal, es un limitante para la reproducción. "Paraguay mula" sería así incapaz de caminar hacia el futuro valiéndose apenas por sí misma, debería ser "montada" y "conducida" para salir adelante. El Mosquito coloca que esta conducción se estaría dando por el Imperio a espaldas de la presidencia Argentina y con la complicidad de Mitre.

\section{Reflexiones finales}

En suma, dentro del contexto de consolidación del Estado nacional argentino, desde el particular lugar de enunciación de El Mosquito, se autoafirma la idea de Argentina, en contraposición a lo Otro, a lo diferente, a lo que no se es y que se rechaza. En ese sentido, Brasil, entendido como un contrincante político por el sentimiento de amenaza que se tenía en relación a este país, ocupa ese lugar de Alteridad y el periódico traduce esas ideas en caricaturas estereotipadas donde se destaca la cuestión racial (población negra) y organización política (monarquía), como elementos de ese Otro, con una carga peyorativa importante, alejándolos de ese ego que pretendía ser moderno y civilizado, categorías que, para la época y visión de Buenos Aires, no serían compatibles con las características recién mencionadas. El chiste racista que atraviesa

\section{CANPHLAC}

Revista Eletrônica da ANPHLAC, ISSN 1679-1061, №. 22, p. 118-146, Jan./Jun., 2017.

http://revista.anphlac.org.br 
varias imágenes presentadas en este trabajo, se coloca como una forma de reforzar la diferencia y de alguna manera, también se presenta como una forma de ser civilizado y moderno.

Es importante aclarar que esto en ningún momento quiere decir que en Brasil esta cuestión se percibiera de esa manera desde "adentro", sino que este discurso es una forma que Argentina configura como forma de auto construcción relacional en función de un Otro diferente que asume las características que se pretenden exógenas en la idea nacional que se forjaba.

Por otro lado, el periódico ilustrado también identifica dentro de ese yoargentino construido, elementos que serían nocivos para su conducción, por entenderlos alineados con la Alteridad y con rasgos de ésta es que lo representa, como es el caso particular de Mitre tratado a lo largo de estas páginas.

Fue posible apreciar a lo largo de todo el trabajo, que Enrique Stein a través de El Mosquito, puso en circulación en la ciudad de Buenos Aires, imágenes sobre Brasil que explotaron formas pasibles de ser interpretadas por algunos sectores de la sociedad porteña de finales del siglo XIX. Así, el mono y la corona se tornan significantes centrales de las narrativas visuales propuestas, ya que se entiende que se encuentran de ese repertorio visual compartido.

El investigador portugués, Rui Zink (apud LUSTOSA, 2011) sostiene que las caricaturas son un lenguaje visual que promueven lo no dicho. Muestran una percepción de la realidad que difícilmente se encuentra en otros códigos de comunicación. Así, El Mosquito explota visualmente ese racismo no dicho en su parte textual y sus contemporáneos son capaces de reconocer las formas que adoptan esas ideas que se expresan a través de imágenes. La alteridad con la que se muestra Brasil para Argentina, adopta visualmente determinados rasgos que en el discurso verbal no se incluyen. El desprestigio del adversario, su inferiorización, su falta de humanidad son herramientas visuales para forjar un sentimiento de identidad superior frente a otro que se presenta jerárquicamente menor, atrasado y anti moderno tanto en lo cultural como en lo político.

Como se vio, esta alteridad proyectada en Brasil - y en menor medida también en Paraguay - que adoptan las imágenes satíricas de El Mosquito, es funcional a la afirmación identitaria de la propia Argentina. Las formas que adoptan los mensajes transmitidos por las narrativas visuales tienen en si un juicio de valor que jerarquiza los

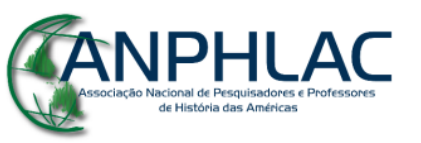

Revista Eletrônica da ANPHLAC, ISSN 1679-1061, №. 22, p. 118-146, Jan./Jun., 2017.

http://revista.anphlac.org.br 
elementos puestos en relación. Argentina siempre se coloca superior, a partir de una escala valorativa que se hizo desde adentro, en relación a los otros Estados que tuvieron lugar dentro de los discursos que se pudieron apreciar a lo largo del trabajo: Brasil por su inferioridad política y composición racial y Paraguay por ser incapaz de salir adelante de manera autónoma.

Ahora, ¿por qué estudiar y analizar estas imágenes? Se considera que estas caricaturas no solo utilizaron la rivalidad y las tensiones latentes en el momento en que fueron puestas en circulación, sino que también fueron propulsoras, promotoras y difusoras de esa rivalidad entre Argentina y Brasil, ayudando a la creación y consolidación de mitos nacionales que necesitaron simbolizar sus amenazas, sus peligros, sus diferencias, sus Alteridades con un objetivo de unificación y homogenización pretendidamente nacional que se mencionó en las primeras páginas. La reflexión a partir de las caricaturas, brinda elementos nuevos a la discusión sobre el asunto, porque trae la perspectiva de lo no dicho y una visión en el plano cultural y simbólico sobre estas disputas que muchas veces se piensan en un ámbito meramente político.

La publicación ilustrada bonaerense de distribución gratuita y dirigida a un público infantil, Historias del Mercosur (2009), es un interesante punto de partida para pensar la contemporaneidad de algunos temas pensados a lo largo de este trabajo.

\section{CANPHLAC}

Revista Eletrônica da ANPHLAC, ISSN 1679-1061, №. 22, p. 118-146, Jan./Jun., 2017.

http://revista.anphlac.org.br 


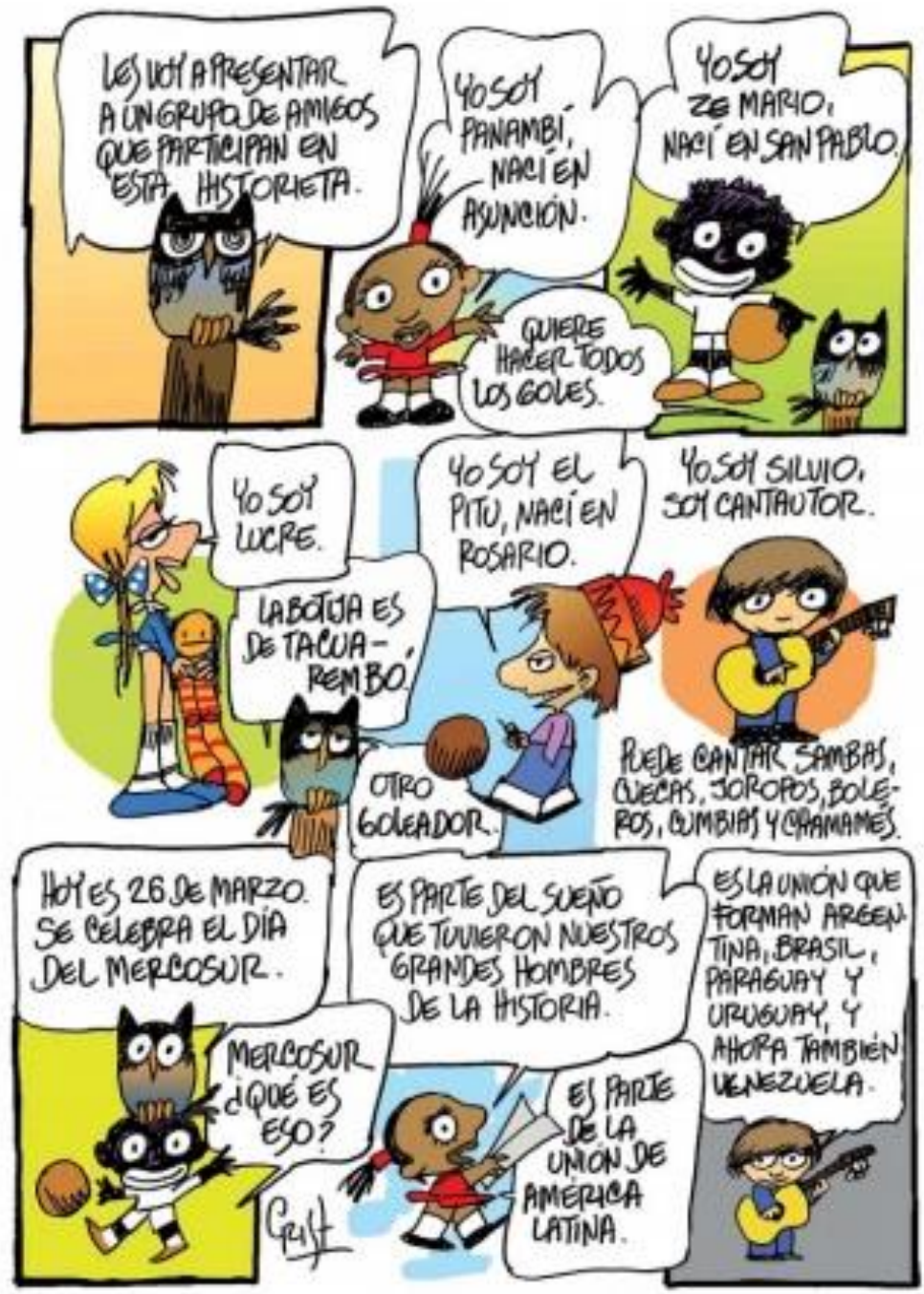

Imagen 10 - Historias del Mercosur, 2009.

- Les voy a presentar a un grupo de amigos que participan en esta historieta. - Yo soy Panambí, nací en Asunción. - Yo soy Ze Mario, nací en San Pablo. - Quiere hacer todos los goles. - Yo soy Lucre. - La botija es de Tacuarembó. - Yo soy el Pitu, nací en Rosario. - Otro goleador. [...]

Dos elementos se destacan de la primera página de esta historia ilustrada, dedicada a presentar a los personajes que transitarán en la narrativa planeada. En primer lugar, Brasil, corporificado en Zé Mario, es un niño negro. Si bien, en esta publicación del siglo XXI esta cuestión no se plantea de manera racista ni como una forma de inferiorización o con una carga peyorativa como se pudo ver a través de las páginas de El Mosquito, se puede afirmar que continúa siendo un recurso de los dibujantes para generar una imagen reconocible sobre lo que sería Brasil. Esto implica que todavía

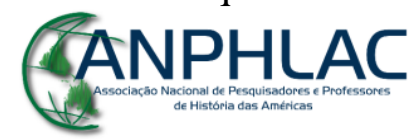

Revista Eletrônica da ANPHLAC, ISSN 1679-1061, №. 22, p. 118-146, Jan./Jun., 2017.

http://revista.anphlac.org.br 
existe un público lector - observador capaz de reconocer estas formas. Por otro lado, y de manera sutil y juguetona, se puede apreciar que la rivalidad continúa colocándose dentro del discurso, esta vez presentada a partir del fútbol: tanto Zé Mario como Pitu, el niño rosarino son goleadores. Teniendo en cuenta los sentimientos que se despiertan en un partido Brasil - Argentina esta colocación del ilustrador y autor de la historieta no es menor. Intenta igualarlos a ambos como goleadores, pero la tensión no se disipa en la realidad.

Hay quienes apunten que a lo largo de la historia y también, contemporáneamente, uno de los obstáculos para la integración de América Latina desde una perspectiva tanto económica, política, social como cultural - es el propio sentimiento de rivalidad que algunos países tienen mutuamente. En el caso particular de Sudamérica, el caso Argentina - Brasil ha sido paradigmático y si bien ha tenido sus vaivenes, la cuestión de la rivalidad - en sus diferentes planos - ha sido una constante a lo largo de la historia de ambos Estados. Por este motivo, entender los diferentes procesos en los cuales estos antagonismos fueron alimentados con el objetivo de mostrar su carácter motivado y de construcción, puede ser un camino interesante para levantar las barreras que fueron inventadas para separar y en su lugar colocar puentes que integren a los pueblos.

\section{Referencias bibliograficas}

ÁLVAREZ, Daniel. De la Estrella del Sur a Internet: Historia de la prensa en el Uruguay. Montevideo: Editorial Fin de Siglo, 2008.

BENJAMIN, Walter. La obra de arte en la época de su reproductibilidad técnica. México D.F.: Editorial Itaca, 2003.

BENDICHO BEREID, José Luis; SAMPAIO BARBOSA, Carlos Alberto (Orgs.). Política e identidade cultural na América Latina. São Paulo: Cultura Académica, 2010. BERETTA GARCÍA, Ernesto. La litografía, la difusión de la imagen y su papel como herramienta propagandística en Montevideo durante el siglo XIX. In: MARONNA, Mónica (Comp.). Historia, cultura y medios de comunicación. Enfoques y perspectivas. Montevideo: Biblioteca Nacional, 2012.

\section{GANPHLAC}

Revista Eletrônica da ANPHLAC, ISSN 1679-1061, №. 22, p. 118-146, Jan./Jun., 2017.

http://revista.anphlac.org.br 
CANDEAS, Alessandro Warley. Relações Brasil-Argentina: uma análise dos avanços e recuos. Revista Brasileira de Política Internacional, Brasília, v. 48, n. 1, 2005. Disponible en: http://www.scielo.br/pdf/rbpi/v48n1/v48n1a07.pdf Acceso en: 05 jul. 2016.

A integração Brasil-Argentina: história de uma idéia na "visão do outro". Brasília: FUNAG, 2010.

DE MARCO, Miguel Ángel. Historia del periodismo argentino: desde los orígenes hasta el centenario de Mayo. Buenos Aires: Educa, 2006.

DORIATOTO, Francisco. O Brasil no Rio da Prata (1822-1994). Brasília: Fundação Alexandre Gusmão, 2014.

. O Império do Brasil e a Argentina (1822-1889). Textos de História, Brasilia, v.

16, n. 2, 2008. Disponible en: http://www.academia.edu/7628332/O_Imp\%C3\%A9rio _do_Brasil_e_a_Argentina_1822-1889 Acceso en: 05 jul. 2016.

ESCUDÉ, Carlos; CISNEROS, Andrés (Dir.). Historia de las Relaciones Exteriores Argentinas. Consejo Argentino Para las Relaciones Internacionales, 2000. Disponible en: http://www.argentina-rree.com/home_nueva.htm Acceso en: 08 jul. 2016.

FUKELMAN, María Cristina; REITANO, María de las Mercedes; RIBEIRO, Eleonora Mora. Representación de la república y la patria en la prensa porteña: variaciones en los tipos iconográficos. In: Anales de las IV Jornadas sobre Arte y Arquitectura en Argentina, La Plata: Facultad de Bellas Artes, 2006, p. 1-10.

KNAUSS, Paulo. O desafio de fazer História com imagens: arte e cultura visual. ArtCultura, Uberlândia, v. 8, n. 12, jan./jun. 2006, p. 97-115.

LUSTOSA, Isabel (Org.). Imprensa, humor e caricatura. A questão dos estereótipos culturais. Belo Horizonte: Editora da UFMG, 2011.

MANGUEL, Alberto. Lendo imagens. São Paulo: Companhia das Letras, 2001.

MINISTERIO DE EDUCACIÓN [Argentina]. Historias del Mercosur. Buenos Aires: Ministerio de Educación, 2009.

MONIZ BANDEIRA, Luiz Alberto. Brasil, Argentina e Estados Unidos: conflito e integração na América do Sul. Rio de Janeiro: Civilização Brasileira, 2010.

PÉREZ VEJO, Tomás. ¿Se puede escribir historia a partir de imágenes? El historiador y las fuentes icónicas. Memoria y Sociedad, Bogotá, v. 16, n. 32, ene./jun. 2012, pp. 17 30.

\section{GANPHLAC}

Revista Eletrônica da ANPHLAC, ISSN 1679-1061, №. 22, p. 118-146, Jan./Jun., 2017.

http://revista.anphlac.org.br 
RAMA, Ángel. La ciudad letrada. Montevideo: Arca, 1998.

RIVERA CUSICANQUI, Silvia. Ch'ixinakax utxiwa: una reflexión sobre prácticas y discursos descolonizadores. Buenos Aires: Tinta Limón, 2010.

SANTOS, Boaventura de Souza. Modernidade, identidade e a cultura de fronteira. Tempo Social, São Paulo: v. 5, n. 5, 1994. Disponible em: http://www.revistas.usp. br/ts/article/view/84940 Acceso en: 7 oct. 2016.

SARMIENTO, Domingo. Conflictos y armonías de las razas en América. Buenos Aires: Imprenta de D. Tuñez, 1883.

SILVA, Rosangela de Jesus. Entre Repúblicas y Monarquía: representaciones visuales de Latinoamérica en la prensa ilustrada argentina y brasileña del siglo XIX. In: PEDRO, Antonio E. de; ROSAURO, Elena (Org.). Cómo ver Cómo: textos sobre cultura visual latinoamericana, Madrid: FOC, 2015.

Imagem e imprensa na América Latina oitocentista: um percurso entre a Argentina e o Brasil. Anais do XXVII Simpósio Nacional de História, Natal, 2013. Disponible em: http://www.snh2013.anpuh.org/resources/anais/27/1371211849_ARQ UIVO_textofinalanpuh2013.pdf Acceso em: 02 jun. 2016.

SZIR, Sandra. De la cultura impresa a la cultura de lo visible. Las publicaciones periódicas ilustradas en Buenos Aires en el siglo XIX. In: BIBLIOTECA NACIONAL, Imágenes, textos y contextos. Buenos Aires: Teseo, 2009.

YAO, Jean-Arsène. Construcciones de lo negro: una lectura ideológica de los bufones de Rosas. Estudios Históricos, Rivera, n. 14, 2015. Disponible en: http://www.estudioshistoricos.org/11/art.6\%20construcciones\%20de\%20lo\%20negro.p df Acceso en: 10 ago. 2016.

\section{CANPHLAC}

Revista Eletrônica da ANPHLAC, ISSN 1679-1061, №. 22, p. 118-146, Jan./Jun., 2017.

http://revista.anphlac.org.br 